\title{
Female Infanticide in the Punjab
}

\section{Capt. A. J. O'brien C.I.E.}

To cite this article: Capt. A. J. O'brien C.I.E. (1908) Female Infanticide in the Punjab, Folklore, 19:3, 261-275, DOI: 10.1080/0015587X.1908.9719830

To link to this article: http://dx.doi.org/10.1080/0015587X.1908.9719830

$$
\text { 曲 Published online: 14 Feb } 2012 .
$$

Submit your article to this journal

Џ Article views: 3

Q View related articles $₫$ 


\section{FEMALE INFANTICIDE IN THE PUNJAB.}

BY CAPT. A. J. O'BRIEN, C.I.R., DEPUTY COMMISSIONER, PUNJAB.

IN the Presidential address to this Society this season ${ }^{1}$ we have the remark that Female Infanticide depends on the food supply, and the laws of marriage on female infanticide. I wish to lay before the Society a series of cases of female infanticide that do not depend on the food supply, and which instead of influencing the laws of marriage are due to their influence. I feel that this account will be the more welcome to this Society, because it shows that one effect may be the result of many different causes, and one action may have several different results. It may be bold for me to speak out in the presence of so much erudition, but there must be many others like myself who rebel at the attempts of the learned to ascribe all results to a single cause. There has been a time when all the gods in the world were connected with the sky and the signs of the zodiac. Now-a-days with equal skill proof is given that every god originated from some heroic human being. That in one part of the world the celestial bodies should be deified, and in another heroes, seems to the ultra-learned as impossible. At a recent meeting a member spoke. of the impossibility of savages treating degenerate gods as dolls, and as an instance argued that no Catholics had yet

i.e. 1907. 
made dolls of the Virgin Mary. It is the same with totemism, early marriage and the theories of the primeval family. All cases whether from China or Peru, Iceland or Samoa are forced into the same mould. The evolution of one race does not give rise to the same results as the evolution of another under different circumstances, and the same may be said of their gods, dolls, totems and social conditions. To accept that there is one cause for female infanticide is like trying to prove one origin for all forms of kingship.

Poverty, no doubt, in certain social conditions leads to infanticide, sometimes of females only, sometimes wholesale. But there are many other causes that lead to the same result. A desire for luxury may lead to infanticide among the comparatively wealthy; fear of disgrace may tend to the same result among the unmarried; while in some places it may be due to a determination to get rid of weaklings. The cases which I shall place before you are due to quite different conditions from those alluded to above. They are confined to the removal of female children only. Before I go on, I must point out that the word infanticide must be allowed to include not only direct destruction, but also neglect, both criminal, and that due to lack of interest. There are constantly cases in which a child's life might be saved by resort to medical advice, or by change of diet or by change of air. I ask you, in considering the statistics that will be laid before you, to calculate also the effect that would be produced in a country where all affection is lavished on the boy, and no expense or trouble is too great to be spent in his preservation, and where a girl is a burden to be tolerated at best.

Now I gather that in a Society like this I shall not be at all popular if I weary my hearers with a string of statistics destined to prove my point. I will, therefore, cut that part of my paper as short as possible. Any 
doubters will find the Punjab Census Volumes of $\mathrm{Mr}$. Rose extremely interesting, and can search in them for further details. It will be accepted that, other things equal, there ought to be a thousand of one sex where there are a thousand of the other. Actually we find variations everywhere. Thus in England there are 1050 male births to 1000 female births, but this is corrected owing to excessive male mortality among infants, and to male emigration, until, as we know, there is a surplusage of females. In the Punjab we find that not only are there I I 10 male births to 1000 female births, but the mortality among females is greater at almost every age. This is the case not only among the tribes that will come under notice, but also among tribes in which females are marketable commodities commanding useful prices. In the arid district of Mianwali, in which I have served for some years, the tribes are Mahomedan, and there is not the least suspicion that the girls are put out of the way at birth, and yet the proportion of infant females falls as low as 839 to 1000 males. In Beluchistan, a country peopled by a similar population, where the struggle for life is equally hard, a like proportion is ascribed by Mr. Hughes Buller simply to the severity of life. Whether he has any valid reasons for this assertion I do not know, but I bring this in because I am very anxious to avoid any tendency to dogmatic assertion. Even among the groups which I shall deal with there may be causes similar to those of Beluchistan and Mianwali, which would in any case reduce the number of females considerably. But it will be admitted that when the figures for female children fall below 850 per mille, they may reasonably be viewed with suspicion, and when to this we add the knowledge that in the pre-British period, and even for some time after annexation, there existed villages without a female child, I do not think that I shall have any difficulty in proving that female infanticide is 


\section{Female Infanticide in the Punjab.}

still in existence in sections which show from 850 to 450 girls to a thousand boys.

The first premise which I must put forward to be noted is that in a greater portion of the tribes of the Punjab, especially those professing the Hindu and Sikh religions, the rule holds good that all girls must have undergone the ceremonial part of marriage before puberty, and that cohabitation commences shortly after puberty appears. The origin of this social custom is the mistrust that Orientals have of the possibility of females to endure a celibate life, and is also due to the penalties which breaches of the social laws entail not only on the offenders, but on the families of these offenders. In our individualistic society those who find it impossible to "walk with clean feet through the streets of experience" bear their own burden. But in India, where the ties not only of family but of clanship are much stronger, the parents, brothers and relations of an offender come under the ban of society. Here thousands are able to and do live a completely celibate life without reproach, but the East has not yet realized the possibility, except perhaps in the case of nuns vowed to the Deity, for whom the bonds of their religion form additional protection.

Having shown that marriage is obligatory for females in the classes under consideration, I now proceed to show that certain other social conditions may place girls in such a position that marriage is impossible for them, and that these two conflicting premises, of which the first, the necessity for marriage, is predominant, lead logically to female infanticide. The social conditions to which I refer are the group of causes that lead to female hypergamy, that is to the rule that girls must marry above them, and conversely that men should marry girls of a lower social standing. The usual cause to which this custom is ascribed is marriage by capture, and this must certainly have had its effect in the Punjab, which 
has always lain in the track of invading armies. I shall, however, show that this is but one of the causes that lead to the same result. We must allow also for sanctity, for the respect due to families descended from holy men. We must allow for the kindly nature of kings and nobles, which impels them to honour their subjects by association with the best-looking of their maidens; and we must also allow for that imitation which is the sincerest form of flattery, and which leads menials to ape the customs of their betters.

The first and perhaps the most interesting class $I$ have to refer to is the saintly class, and as is the case with perversions of religious ideas elsewhere, the worst results almost are attained in this class. Let me point out here what a debt of gratitude we owe to those who, when the Christian religion was going through a similar form of evolution, decided that the priests from whom the majority of saints were drawn must be celibate. It is obvious that just as our society papers pay regard to an Honourable, because he or she is the offspring of a peer, it is impossible to conceive a race that paid great homage to a St. Jerome, a St. Augustine, or a St. Patrick not paying a considerable degree of respect to their children, had they had any. In India among those for whom celibacy is not the badge of a saint, we have the latter condition. The children of holy men are holy too-not perhaps as holy as their parents-but still holy. This sanctity will descend for several generations, and the time when the sanctity becomes too diffused for further respect varies with the degree of sanctity attained by the original holder. I must not continue this subject, which is in itself a fascinating one, but will merely point as a well-known example to the respect paid all over the East to the Syeds, the descendants of Mahomed's daughter, and of Ali. Given this fact, it is clear that not only the sons of holy men are holy, but their daughters are also entitled 
to veneration. This being so, it follows that while the sons of holy men can honour the daughters of mere mortals by association with them, for a layman to approach a saintly damsel is sacrilege. This law works both ways. Not only will the relations of a saintly girl feel themselves disgraced by the mere thought of a relationship with a humbler individual, but that individual himself will be restrained from offering the indignity of a proposal to one so vastly his superior. Among the polygamists this may do no harm. The Syed alluded to above marries his cousin as his first wife, and takes other lowlier females as well. But Hindus and Sikhs are in the main restricted to one wife, and hence diffculties arise. Thus while the males of the saintly caste have an unlimited field of choice, and competition to secure them as husbands may lead to handsome dowers accompanying their brides, the godly females have to compete in a market already overcrowded. Hence the result that if they are kept alive in races where marriage is a necessity and monogamy the rule, the parents must at all hazards purchase husbands for them at whatever the cost before the girls attain the age of puberty. The logical consequences of this is that when a female child is born in such a family the parents calculate the chance of her marriage, and if they do not see a probability of raising the necessary dower in time, they decide to remove her from the world before she has had time to realize her existence in the world.

Now let us take another form of society that leads to the same result. When the great Moghul King Akbar was consolidating his empire he came to the conclusion that by accepting wives from various leading tribes he would link them in kinship with himself and thus obtain their loyalty. Among the other girls that he married in this way were girls of some Punjab Jat Clans. His successors Shahjehan and Aurangzeb 
followed his example, with the result that a dozen or so of the stout Northern Clans were connected by marriages with the Emperors of Delhi. Now look at the effect this had on the aforesaid Jat Clans. Their males obtained distinction by the distinction bestowed on their clan. Their daughters had married Royalties. Obviously it followed that it was impossible to demean themselves by allowing other daughters to marry subjects. Hence if daughters were born into the world they must be removed from the world again. As among the Saints, the men of the Royal Jat Clans could find wives from the humbler circles. However, wholesale destruction was found to be too much, and a modification was made later on, by which these clans if they kept the girls alive could give them to men of the other clans with like pretensions. But here as before a difficulty still remained. The girls of the families that moved in Royal circles could only marry men of other families with similar connections, but these men were able to get girls from numerous families only too proud to give them. It followed that a very heavy dowry was necessary for the purchase of husbands by these superior girls, and only where it was in sight could they be kept alive. Statistics show clans with proportions as low as 572,524 and 574 .

Now let us look at the Khatri organization. There are variations in it from district to district, but roughly speaking the tribe is arranged as follows: At the head of the social scale we have four clans called the DhaiGhar or two and a half house group; below them are the Chahar-Ghar or four house group; after them the Bari or twelve house group; and lastly the Bunjahi or fifty-two house group. The above Khatri organization is hypergamous for females, or rather here we have a variation in that girls may also marry on their own level, but never beneath them. I forgot to state that 
among Hindus and Sikhs it is almost universally the rule that one must never marry within one's own house. Hence the girls of the Bunjahi group can marry on their own level into any of the other fifty-one clans of the Bunjahi, or above into the twelve Bari, or four Chahar-Ghar or four Dhai-Ghar clans. They have, therefore, a wide matrimonial field. The Bari girls have eleven clans on their level and two groups of four above them. The Chahar-Ghar have three other Chahar-Ghar and four Dhai-Ghar sections that they may join, and finally the Dhai-Ghar can only marry into the other three clans of their own group, or rather as near relations of the mother are also barred, into two and a half houses as designated in the group named. Conversely the Dhai-Ghar men can marry into many groups on the same level or down below, and they therefore have the parents of Dhai-Ghar girls at a disadvantage, should the latter come forward with only a small dot. Hence we have reasons preparing us to find female infanticide among the Dhai-Ghars, and the statistics show that our suspicions are not ill-founded.

Why the Khatris are thus organized is not well known, and I cannot tell you how it comes that the Dhai-Ghar Clans are able to arrogate a superior position. It is not the least use turning to the clans themselves for information. Although the Khatris in the Punjab are among the most keen-witted and best educated of Punjabis, their minds are not turned to the historical or antiquarian, and I have never been able to obtain explanations for the clan names derived from trees, animals and flowers from the members of the clans themselves. In the case of the Rajputs, however, we are on firmer ground. They are in the mainnothing can be said dogmatically about anything Indian-they are in the main related in a near or far degree to princes who have exercised rule at one time 
or another over principalities of varying sizes. Hence Rajputs can always obtain brides from non-Rajput tribes, to whom of course they would not think of giving their daughters. Hence, again, all Rajputs are to a greater or less degree in a difficulty of disposing of their daughters. But the Rajputs among themselves are arranged in tables of precedence which vary immensely according to the status obtained by their ancestors. It would be impossible for me to give details of their grouping in an easily intelligible form. In one district a clan might have obtained power and pre-eminence that it did not achieve in another. It might in the one place be at the top, and in another in the middle of the social ladder. But whatever the grouping may be, the status all turns on the question of the marriage of the daughters. Would group A give or take a daughter from group B? It may safely be said that marriage is expensive for every Rajput maiden, and temptations to limit families must always exist, but owing to this constant change of status it is only when we turn to the Rajput families of the hill district of Kangra, which claim and are admitted to possess the bluest blood, that we get really distinctive figures. Where there are a thousand boys, there are in some of these sections from 500 to 450 girls.

The last and most curious feature to which I shall call your attention is that some of the menial castes in certain places have as small a percentage of female children as their more distinguished neighbours. This is due to the fact that they organize themselves into groups, which in some places reflect the organizations of the masters whom they serve. I have heard that the coachman and butlers of great men are alluded to in their own circles as the Duke of Westminster or Lord Rosebery, and that their status among lesser fry is like that of their masters. Similarly it is obvious 


\section{Female Infanticide in the Punjab.}

that a sweeper who sweeps for a Durbari Jat family is superior to the menial who plies his broom on behalf of Jats of a lower status, and it is not to be expected that he will give his daughter to such low people, though willing enough to accept homage in the form of a maiden from below. Nothing, perhaps, is so surprising to the uninitiated as the fact that those beings that we are accustomed to consider in India to be the lowest of the low-the cobbler, the sweeper or the groom-have as many grades of precedence and social distinctions as the nobility, gentry and priesthood. The sweeper who eats carrion or lizards, may give his daughter to the sweeper, who will eat the leavings of Europeans, but will never be honoured by an exchange of girls. The Plantagenet or Knight of the lowly broom serving a European may give his daughter to a fellow casteman who observes the Mahomedan rules of diet. The Mazhabi Sikhs-sweepers by origin, who having accepted the Sikh religion are recruited into our Pioneer regiments-are divided into two grades, whom we may call the "old originals" and the "latterday men," with the usual results. The first sect take the girls from the latter but do not reciprocate, and both will take brides from the common herd of nonSikh sweepers mentioned above. The result is that they have about as bad a proportion of females as is to be found anywhere-703 to 1000 of the other sex. You can see that this state of affairs tends to multiply itself, and nothing but the closest intimacy and most minute statistics could reveal the truth. I see that there are only 800 girls among Sikh Barbers to 1000 boys. If we studied their organization, which I have not done, we should probably find, as we have in the cases above, that the low ratio was almost automatic. Another custom which might have the same result is that which prevails in the South-East of the 
Punjab. Girls of some classes must always marry out of their own village and into a village situated to the west of them. Where the line is drawn I do not know, and I have no personal knowledge of the custom, but presuming it to exist and supposing, as is not likely, that the custom underwent no modification, you will see that we must reach a far western village where female infanticide must be practised.

It may be asked why the Government does not prevent such evils. The answer is, that in the first place a great improvement has taken place owing to the action of Government. Formerly there were villages with no girl children at all in the whole village. We have only been in the Punjab for sixty years-not a very long period to revolutionize a deep-rooted custom. In fact, the repressive action taken involves an enforcement of collective responsibility and a modified system of espionage, which would be intolerable but for the necessity of such action. In the second place, the real point is, that all social improvement must come from within, and where a whole village is agreed on the beneficial effect of female infanticide, it is very difficult for an alien Government to obtain proof of any one crime. There may be less drinking in a Prohibitionist State, but, as is well known, it is impossible to ensure that there shall be no drinking there. We with Western ideas may think it a terrible thing to take a child's life, and would at any rate consider that its mother, at least, would make some defence for its life. But those who practise these customs think otherwise. Consider that the mother has been educated to consider that to bring a female child into the section into which she has married is a crime, and the child itself an abomination and a disgrace. Would she not, if she did give birth to such a child, look on it as some mothers would on a Richard Calmady, and wish that the monster should be taken away from her at once? Do not let me give my hearers 


\section{Female Infanticide in the Punjab.}

the idea that I make any defence of such practices. I only wish to show that it is of no use attempting to examine social evils without looking for a bit at the point of view of those that practise the evil.

It is satisfactory to note that there are signs of great improvement from within, and of readjusting the social laws to suit present conditions. It is in this readjustment that the only real hope of success lies. I think I may have made clear to you that as long as the organizations to which I have referred are rigid, there is no hope of improvement. Fortunately, however, the silly generalization about the "Changeless East," like all generalizations, is entirely a false one. The caste organizations, far from being rigid, are constantly on the change, and the repressive influence of our Government has its effect as well as improvements in ideas. Just as in Prohibition States whole generations grow up, who have no desire to break the prohibition laws, so the fact that female infanticide is discouraged strongly wherever examples can be made helps to increase the numbers of those who wish to do away with the practice. Thus the Bedi Khatris, sanctified by having produced Sikh Gurus, who have at present only 668 girls to a 1000 boys, not only interchange now-adays with the Sodhis, another holy clan, who do not really belong to their group, but, breaking all the standard rules of exogamy, have started inter-marriage within their own clan. Among the other Khatris there have been other alterations. The lower clans have rebelled against giving their girls to the superior classes, and we thus see the breaking off of blocks like the Athzatias or Eight-clan men from the main organization who only interchange girls with each other on level terms. Every rebellion of this kind causes a diminution of possible brides to the upper castes, who therefore are stimulated to keep their own daughters alive for purpose of exchange. Or.again, we find families ready to accept degradation in order to 
keep their daughters alive. Men of the two and a half houses will sometimes marry their daughter to four house or twelve house people. This entails degradation of the whole family concerned into the lower house, but the degradation is occasionally accepted and the females can be kept alive. Hence the four top clans, with a proportion of 800 to 880 female children, do not show up in the statistics so badly as if the two and a half house figure had been kept separate. There are other curative methods at work. A Jat of the top group may give his daughter to a Rajput. A poor Rajput may win wealth by accepting as a son-in-law a Prince of the distiller class. In fact, one way or another, the practice which I describe, and which was a very real one in the past, is disappearing for good before our civilization and our methods of government.

Yet the tendency towards hypergamy is always liable to crop up even in unlikely places. On the banks of the Indus there are a number of well-to-do Mahomedan farmers, among whom much rivalry and party feeling exists. One such found a difficulty in obtaining a husband suitable in his eyes to be married to his sister, so he kept her unmarried in his house long after she had come of age. It followed that some of the other yeomen, in order to show that they were as good as he was, had to keep their sisters unmarried also. As they were Mahomedans, there were no religious laws binding them to marry. Naturally, as in the similar case of Aurangzeb's two unmarried sisters, one heard whispers of scandal, but intrigue is dangerous in such households. The difficulties of mating Royal and Noble females has always been a great one. If caste rules are relaxed, as in the case of the Duke of Fife, we hear one set of objections; and if the hedge between religions is knocked down, as with the recent Spanish marriage, there are other protests. The Pharaohs and other kings disposed of their unmarried 
sisters by marrying them themselves. The argument is simple. A king cannot give his sister to a mere subject. She must be married. He is the only possible husband and he marries her accordingly. In Bengal the surplusage of females at the top hypergamous ladder is cured by Kulinism. This means that there exists a top group of professional married men, who, for a consideration in each instance, will condescend to ally themselves in matrimony with fifty or sixty girls at a time. The rule is that girls must be married is thus adhered to, and even if a girl gets but the sixtieth part of a husband, at least she can show her marriage lines to the public.

Perhaps I can best end this paper by showing a byeproduct of the practice of hypergamy. In the first place, at the top of the tree it is so hard for a maiden to find a husband that it is absolutely imperative that no unfair competition should exist. Hence we find that widow re-marriage is absolutely prohibited. This from their spectacles is perfectly reasonable. A girl is lucky to get married, and if after marriage, even if it happen that she may never have visited her husband, she loses him, that is her misfortune. It is bad luck, no doubt, but that is no reason for her invading the over-stocked market again. On the other hand, while bridegrooms are few at the top of the scale, and have to be purchased with substantial dowries, as we go lower, men increase in number and girls have a wider field. We therefore find that the men at the bottom have to purchase their wives-or, to put it more euphemistically, have to pay the parents the cost of a girl's upbringing. Even then they cannot all be mated, and as nowhere do we hear of the slaughter of male children to balance the account, we find other social correctives in veiled polyandry and widow re-marriage. Where women are few, and only the elder brother can marry, he is not supposed to pay much heed to the behaviour of his brothers to his wife. When her husband 
dies, unlike the ladies above, she is much too valuable to be wasted, and is promptly married by the next brother. See here how again we have a similar result from dissimilar causes. This practice is entirely different from the Levirate custom. There a woman married her husband's brother or nearest kinsman, not because he wanted to, but because she had a right to claim that he would perpetuate through her the race of her deceased husband. Here a woman leaves her family and enters another by marriage, and when her husband dies, she has no right to dispose of herself, but remains with her husband's kinsfolk. There are many other aspects to this custom and to the main subject of my thesis, but I do not pretend to do more than give a sketch of some aspects only. 